\title{
CRIOPRESERVAÇÃO DE SEMENTES PRÉGERMINADAS DE ORQUÍDEAS TROPICAIS
}

Leandro Haruo Sawamura ${ }^{1}$, Nelson Barbosa Machado Neto ${ }^{2}$, Ceci Castilho Custódio ${ }^{2}$, Silvério Takao Hosomi ${ }^{3}$

${ }^{1}$ Discente do curso de Ciências Biológicas Bacharelado da UNOESTE. ${ }^{2}$ Docente do Curso de Doutorado em Agronomia pela UNOESTE. ${ }^{3}$ Doutorando em Agronomia pela UNOESTE. E-mail: takao@unoeste.br. Financiado pelo Conselho Nacional de Desenvolvimento Científico e Tecnológico - CNPq.

\section{RESUMO}

As orquídeas representam o maior grupo entre as Angiospermas em número de espécies. São muito utilizadas para ornamentação, tanto como plantas de vaso como flores de corte. Algumas espécies têm grande importância econômica e estão sob risco de extinção. $O$ estabelecimento de bancos de sementes é fundamental para a conservação de espécies cultivadas e silvestres, porém, nem sempre é possível, pois algumas espécies possuem sementes que não toleram dessecação ou baixas temperaturas, sendo possível optar-se por outras formas como propágulos, pólen, gemas e outras. Sementes germinadas armazenadas a temperatura de nitrogênio líquido $\left(-196^{\circ} \mathrm{C}\right)$ podem ser uma opção. O presente estudo visa avaliar o efeito do tempo de exposição e de três crioprotetores no condicionamento para crioconservação à -196 ํ C de sementes pré germinadas de Cattleya nos tempos: 0, 1, 3, 6 e 24 horas de condicionamento nos crioprotetores.

Palavras chave: Crioconservação, Crioprotetores, Sobrevivência, Orchidaceae

\section{INTRODUÇÃO, REVISÃO DE LITERATURA E JUSTIFICATIVA}

As orquídeas representam o maior grupo entre as angiospermas em número com cerca de 20000 a 35000 espécies sendo que, no Brasil, há cerca de 10\% das espécies desse grupo (DRESSLER 2005; SOUZA; LORENZI 2008), ocorrendo em quase todos os ecossistemas da terra com exceção da zona polar (NIKISHINA et al. 2001, 2007). Algumas espécies têm grande importância econômica, um exemplo é a essência de baunilha extraída dos frutos de Vanilla planifolia; algumas outras espécies possuem alto valor ornamental, como por exemplo, as Cattleyas, Phalaenopsis, Dendrobium entre outras (JUDD et al. 2009). A sua intensa exploração tem acarretado extinção de espécies da população além da degradação do seu habitat natural (HOSOMI et al. 2011). A exploração do habitat também é fator que colabora para o desaparecimento de muitas espécies (KOOPOWITZ 2001).

O estabelecimento de bancos de sementes é fundamental para a conservação das espécies cultivadas e silvestres (ALVAREZ-PARDO; FERREIRA 2006; SEATON; PRITCHARD 2008). As informações para armazenamento de sementes de orquídeas são limitadas, e ainda há algumas divergências entre autores quanto ao que são consideradas condições mais adequadas (SHOUSHTARI et al. 1994; PRITCHARD; SEATON 1993; PRITCHARD et al.1999; MACHADO NETO; CUSTÓDIO 2005a, SEATON; PRITCHARD 2008). Algumas podem ter duração curta, apenas três 
meses, quando armazenadas secas a $4^{\circ} \mathrm{C}$ (MACHADO NETO; CUSTÓDIO 2005b), enquanto o armazenamento em temperatura mais baixa (sub-zero, $-18^{\circ} \mathrm{C}$ ) é considerado mais adequado para armazenamento de longo prazo (SEATON; PRITCHARD 2008).

Apesar de algumas orquídeas, ameaçadas de extinção, poderem ser propagadas em meio apropriado in vitro a partir de sementes (LONG et al. 2010; DUTRA et al. 2009; ÁVILA-DIAZ et al. 2009, HOSOMI et al. 2012), esta não é uma estratégia fácil de seguir para todos os taxa. Além disso, as sementes de algumas espécies não podem ser armazenadas a baixa temperatura e umidade, pois expressam características intermediárias ou recalcitrantes, uma vez que não toleram dessecação, ou armazenamento em condições de câmara fria (MACHADO NETO; CUSTÓDIO 2005b), por não se apresentarem como ortodoxas clássicas (ELLIS; HONG 2007). Como alternativa, bancos de semente têm o potencial de longo prazo de armazenamento de um grande número de propágulos (IUCN 1996, MACHADO NETO; CUSTÓDIO 2005b), o que seria facilitado em orquídeas, pois como as sementes destas são pequenas, cada cápsula pode conter de centenas a milhões de sementes (ARDITTI; GHANI 2000).

A criopreservação pode ser uma alternativa para plantas que apresentem sementes recalcitrantes, i.e., que não tolerem dessecação ou diminuição de temperatura. Neste caso, a estocagem de embriões seria a alternativa, em ultracongelamento $\left(-80^{\circ} \mathrm{C}\right)$ ou criocongelamento (BENSON 2008).

Em orquídeas, alguns experimentos já foram conduzidos com pólen (VENDRAME et al. 2008), sementes (THAMASIRI 2000, WANG et al. 2011) ou com embriões (NIKISHINA et al. 2001, 2007) com resultados promissores. Todavia, alguns resultados obtidos por este grupo demonstram que embriões em estágio 1 (SEATON; HAILES; 1989) são pouco tolerantes à crioconservação (dados não publicados).

De acordo com CROWE et al. (1988) estruturas acumuladoras de açúcares, como sementes e pólen, na maioria das angiospermas, apresentam tolerância a crioconservação. Todavia, sementes de orquídeas apresentam reservas lipídicas o que poderia tornar mais difícil a conservação deste tipo de sementes por meio de crioconservação. A remoção da água, por meio de crioprotetores químicos que ocasionam a vitrificação do citoplasma e das membranas é uma alternativa para isto.

Alguns crioprotetores utilizados são à base de DMSO (dimetilsulfóxido), etilenoglicol, metanol, glicerol e propileno-glicol, todavia a exposição prolongada a estes materiais pode ser danosa, pois segundo Kartha (1985) e Sakai (1995) essas soluções possuem alta citotoxidade e podem acarretar a morte celular. Neste ponto, os açucares também são considerados agentes 
vitrificadores, sendo utilizados como crioprotetores e mostrando eficiente estabilidade na membrana celular durante o congelamento. O efeito protetor dos açucares como a trehalose, sacarose e glucose pode estar associado à vitrificação das membranas citoplasmáticas (HIRSH 1987; KOSTER 1991; LEOPOLD 1990). Sementes de orquídeas pré condicionadas com sacarose forma mais responsivas ao tetrazólio que sementes secas pré condicionadas com água (HOSOMI et al. 2011)

\section{OBJETIVO}

Avaliar o comportamento de sementes pré-germinadas de Cattleya intermédia, C.milleri e C.warnerii frente aos períodos: 0, 1, 3, 6 e 24 horas de exposição a três crioprotetores durante armazenamento criogênico $(-196$ ㄷ) $)$.

\section{MATERIAIS E MÉTODOS}

As sementes de Cattleya intermedia serão deixadas nesta condição por uma semana, após o que serão limpas de debris e sementes mortas por centrifugação diferencial em sacarose e submetidas ao pré-condicionamento com os crioprotetores.

Os crioprotetores utilizados no experimento serão:

1. D.S.G com $7,81 \%$ DMSO, $9,21 \%$ glicerol e $62,45 \%$ sacarose

2. PVS2 com $30 \%$ de glicerol, $15 \%$ de DMSO, $15 \%$ de etilenoglicol;

3. PVS3 com $40 \%$ de glicerol, $40 \%$ de sacarose;

Todos adicionados de $1 \mathrm{~mL}$ dos estoques do meio MS (MURASHIGE; SKOOGE; 1962), totalizando $7 \mathrm{ml}$, mais $2 \mathrm{~g}$ de sacarose e completados para $100 \mathrm{~mL}$ com água destilada.

As sementes germinadas serão mantidas nesta mistura, por $0,1,3,6$ e 24 horas a $25 \pm 3$ 으. As mesmas serão aliquotadas em tubos criogênicos, e mantidas em nitrogênio líquido por períodos determinados de zero, três, seis e nove meses.

Passado cada período de estocagem, um frasco de cada tratamento será retirado, descongelado à $40^{\circ} \mathrm{C}$ e os embriões, lavados em meio líquido e colocados para crescer em meio MS solidificado com agar $\left(6 \mathrm{~g} \mathrm{~L}^{-1}\right), \mathrm{pH}$ 5,6. Uma parte das sementes será testada para tetrazólio para confirmar a viabilidade (HOSOMI et al., 2011). 


\section{RESULTADOS}

O uso de crioprotetores em sementes de orquídeas já foi realizado em sementes (THAMASIRI 2000, WANG et al. 2011) ou com embriões (NIKISHINA et al. 2001, 2007), com relativo sucesso em outras espécies que não o gênero Cattleya.

Em resultados preliminares, deste grupo, os crioprotetores utilizados foram testados para sementes e permitiram aferir que as sementes secas a $6 \%$ de água, já apresentavam condições suficientemente boas para serem crioconservadas, sendo superior este tratamento aos crioprotetores. Todavia, algumas espécies não toleram o processo convencional de armazenamento (MACHADO-NETO; CUSTÓDIO 2005a) sendo necessário buscar alternativas diferentes de armazenamento para este tipo de material.

Apesar deste tipo de técnica ser utilizada com relativa facilidade para sementes ricas em açúcares, nem sempre logra sucesso em sementes ricas em óleo como é o caso das orquídeas.

Ao serem retirados do nitrogênio líquido, os protocórmios foram descongeladas em água à $45^{\circ} \mathrm{C}$, ocorrendo a morte de todos os embriões e em todos os crioprotetores. Tal procedimento foi adotado por propiciar um descongelamento mais rápido e evitar a formação dos cristais de água no interior da célula.


Figura 1. Fotografias dos embriões de Cattleya intermedia submetidos ao teste de tetrazólio, observados no microscópio óptico com aumento 40 vezes. I - Embriões após o tratamento com o crioprotetor GSD no período de 0 hora. II - Embrião após o tratamento com GDS no período de 3 horas. III - Embrião após o tratamento com GDS no período de 6 horas. IV - Embrião após o 
tratamento com o crioprotetor PVS2 no período de 0 hora. V - Embrião após o tratamento com PVS2 no período de 3 horas. VI - Embrião após o tratamento com PVS2 no período de 6 horas. VII - Embrião após o tratamento com o crioprotetor PVS3 no período de 0 hora. VIII - Embrião após o tratamento com PVS3 no período de 3 horas. IX - Embrião após o tratamento com PVS3 no período de 6 horas.

\section{CONCLUSÕES}

O processo de crioconservação não foi homogêneo para as espécies estudadas. Mesmo se baseando em um protocolo pré-existente, este não funcionou para estes materiais.

De acordo com as imagens do Teste de Tetrazólio, foi possível perceber que os crioprotetores já se apresentam com elevada toxidade, danificando os tecidos vegetais. Logo após, ao sofrer um estresse ainda maior, o qual é o nitrogênio líquido, os embriões não sobrevivem.

\section{REFERÊNCIAS}

ALVAREZ-PARDO, V.; FERREIRA, A.G. Armazenamento de sementes de orquídeas. Rev Bras Sementes, 28:92-98, 2006. http://dx.doi.org/10.1590/S0101-31222006000100013

ARDITTI, J.; GHANI, A.K.A. Numerical and physical properties of orchid seeds and their biological implications. New Phytol, 145:367-421, 2000. http://dx.doi.org/10.1046/j.14698137.2000.00587.x

ÁVILA-DIAZ, I.; OYAMA, K.; GÓMEZ-ALONSO, C.; SALGADO-GARCICLIA, R. In vitro propagation of the endangered orchid Laelia speciosa. Plant Cell Tiss Organ Cult 99:335-343, 2009. http://dx.doi.org/10.1007/s11240-009-9609-8

BENSON, E.E. Cryopreservation theory In: Reed BM (ed) Plant Cryopreservation: a practical guide. Springer, New York, pp 15-32; 2008. http://dx.doi.org/10.1007/978-0-387-72276-4_2

BRADFORD, M.M. A rapid and sensitive method for the quantitation of microgram quantities of protein utilising the principle of protein-dye binding. Anal Biochem, 72:248-54, 1976. http://dx.doi.org/10.1016/0003-2697(76)90527-3

Brasil. Ministério da Agricultura. Regras para análises de sementes. SNAD/DNDV/CLAV, Brasília. 2009. 399p.

CROWE, J.H.; OLIVER, A.E.; HOEKSTRA, F.A. \& CROWE, L.M. Stabilization of dry membranes by mixtures of hydroxyethyl starch and glucose: the role of vitrification. Cryobiology, 35: 20-30, 1997. http://dx.doi.org/10.1006/cryo.1997.2020

DRESSLER, R.L. How Many Orchids Species. Selbyana 26:155-158, 2005. 
DUTRA, D.; KANE, M.E.; RICHARDSON, L. Asymbiotic seed germination and in vitro seedling development of Cyrtopodium punctatum: a propagation protocol for an endangered Florida native orchid. Plant Cell Tiss Organ Cult 96:235-243, 2009. http://dx.doi.org/10.1007/s11240-0089480-z

ELLIS, R.H.; HONG, T.D. Seed longevity - moisture content relationships in hermetic and open storage. Seed Sci \& Technol 35:423-431, 2007.

FERREIRA, D.F. SISVAR: um programa para análises e ensino de estatística. Revista Symposium 6:36-41, 2008.

HIRSH, A.G. Vitrification in plants as a natural form of cryoprotection. Cryobiology, 24: 214-228, 1987. http://dx.doi.org/10.1016/0011-2240(87)90024-1

HOSOMI, S.T.; SANTOS, R.B.; CUSTODIO, C.C.; SEATON, P.T.; MARKS, T.R.; MACHADO-NETO, N.B. Pre-conditioning Cattleya seeds to improve the efficacy of the tetrazolium test for viability. Seed Sci Technol, 139:178-189, 2011.

HOSOMI, S.T.; CUSTODIO, C.C.; SEATON, P.T.; MARKS, T.R.; MACHADO-NETO, N.B. Improved assessment of viability and germination of Cattleya (Orchidaceae) seeds following storage. In Vitro Cell.Dev.Biol._Plant, 48:127-136, 2012. http://dx.doi.org/10.1007/s11627-011-9404-1

IUCN. Orchids: Status survey and conservation action Plan. Hagsáter E.; Dumont, V. (eds). Graphic Express, Los Gatos; 1996.

JUDD, W.S.; STEVENS, P.F.; KELLOG, E.A.; DONOGHUE, M.J.; CAMPBELL, C.S. Sistemática vegetal: um enfoque filogenético. 3.ed. Porto Alegre: Artmed, 2009.

KARTHA KK. Meristem culture and germplasm preservation. In: Kartha, K.K. (Ed.) Cryopreservation of plant cells and organs. Boca Raton, Florida, 1985. pp. 115-134.

KOOPOWIIZ, H. Orchids and their conservation. Timber Press, Portland, Oregon; 2001.

KOSTER, K.L. Glass formation and desiccation tolerance in seeds. Plant Physiol, 96: 302-304, 1991. http://dx.doi.org/10.1104/pp.96.1.302

LEOPOLD, A.C. Coping with desiccation. In: Alscher, J.G. \& Cumming, J.R. (Eds) Stress responses in plants: adaptation and acclimation mechanisms. New York, Wiley- Liss, 1990. pp. 37-56.

LONG, B.; NIEMIERIA, A.X.; CHENG, Z.Y.; LONG, C.I. In vitro propagation of four threatened Paphiopedilum species (Orchidaceae). Plant Cell Tiss Organ Cult 101:151-162, 2010. http://dx.doi.org/10.1007/s11240-010-9672-1

MACHADO-NETO, N.B.; CUSTODIO, C.C. A medium for non-commercial sowing of orchid seed. Selbyana 26:316-317, 2005a.

MACHADO-NETO, N.B.; CUSTODIO, C.C. Orchid conservation through seed banking: ins and outs. Selbyana 26:229-235, 2005b. 
MAGUIRE, J.D. Speed of germination aid in selection and evaluation of seedling emergence and vigor. Crop Sci 2:176-177, 1962. http://dx.doi.org/10.2135/cropsci1962.0011183X000200020033x

MURASHIGE, T.; SKOOG, F. A revised medium for rapid growth and bio-arsays with tabacco tissue cultures. Physiologia Plantarum, v.15, p.473-497, 1962. http://dx.doi.org/10.1111/j.13993054.1962.tb08052.x

NIKISHINA, T.V.; POPOV, A.S.; KOLOMEITSEVA, G.L.; GOLOVKIN, B.N. Cryopreservation of Seeds and Protocorms of Rare Temperate Orchids. Russ J Plant Physiol, 54:121-127, 2007. http://dx.doi.org/10.1134/S1021443707010189

NIKISHINA, T.V.; POPOVA, E.V.; VAKHRAMEEVA, M.G.; VARLYGINA, T.I.; KOLOMEITSEVA, G.L.; BUROV, A.V.; POPOVICH, E.A.; SHIROKOV, A.I.; SHUMILOV, V.Y.U.; POPOV, A.S. Cryopreservation of Seeds of Some Tropical Orchids. Doklady Biochem and Biophy, 378:231-233, 2001. http://dx.doi.org/10.1023/A:1011585801668

PRITCHARD, H.W.; POYNTER, A.L.C.; SEATON, P.T. Interspecific variation in orchid seed longevity in relation to ultra-dry storage and cryopreservation. Lindleyana 14: 92-101, 1999.

PRITCHARD, H.W.; SEATON, P.T. Orchid seed storage: Historical perspective, current status, and future prospects for long- term conservation. Selbyana 14:89-104, 1993.

RIZHSKY, L.; HALLAK-HERR, E.; VAN BREUSEGEMM, F.; RACHMILEVITCH S, BARR JE, RODERMEL S, SAKAI A. Cryopreservation of germplasm of woody plants. In: Bajaj YPS. (Ed.) Biotechnology in agriculture and forestry. vol 32. Cryopreservation of plant germplasm I. Berlin, Heidelberg, New York, Springer-Verlag, 1995. pp 53-69.

SEATON PT; HAILES NSJ. Effect of temperature and moisture content on viability of Cattleya aurantiaca seed. In: Pritchard HW (Ed.) Modern methods in orchid conservation: the role of physiology, ecology and management. Cambridge University Press. 1989. p.17-29. http://dx.doi.org/10.1017/CBO9780511551307.003

SEATON PT; PRITCHARD HW. Life in the freezer. Orchids, 77:762-773, 2008.

SHOUSHTARI BD; HEYDARI R; JOHNSON GL; ARDITTI J. Germination and viability staining of orchid seeds following prolonged storage. Lindleyana 9: 77-84, 1994.

SOUZA VC, LORENZI H. Botânica sistemática - Guia ilustrado para identificação das Fanerógamas nativas e exóticas no Brasil, baseado em APG II. 2. Instituto Plantarum, Nova Odessa; 2008.

THAMMASIRI K. Cryopreservation of seeds of a Thai orchid (Doritis pulcherrima Lindl.)by vitrification. Cryo Letters 21:237-244, 2000.

VENDRAME WA, CARVALHO VS, DIAS, JMM, MAGUIRE, I. Pollination of Dendrobium Hybrids Using Cryopreserved Pollen. Hortsci, 43:264-267. 2008.

WANG RX; SONG XQ; HE MG; SONG SQ. Developmental changes of cryo-tolerance associated with stored reserve accumulation of Doritis pulcherrima (Orchidaceae) seeds. Seed Sci Tech, 39: 271-281, 2011. 